\title{
Contornos Humanísticos em Gestão
}

\author{
Alves, Solange Evangelhista; Matos, Patricia Midoes de \\ Instituto Central do Hospital das Clinicas da FMUSP — solange.sea@hc.fm.usp.br
}

Introdução o relato de experiência desse trabalho de humanização assume contornos a partir do momento que há consciência da importância do pensar a educação como um fator de aperfeiçoamento pessoal e profissional pelos gestores e pelos colaboradores em conjunto. As ações foram desenvolvidas a partir de estratégias de gestão e qualidades dos serviços prestados, formação ética e posturas humanísticas salientando o atendimento ao cliente interno e externo. a partir de diagnóstico através de conversas, observação geral da execução do trabalho no setor, as atividades foram previstas divididas em dois semestres em 2013. Cada grupo de atividades contemplou um cronograma de três meses. o plano Piloto foi pensado para os meses de abril, maio e junho com o título Conhecimento, Liderança e Organização e, no segundo semestre o Projeto Educacional - Gerenciamento de informações e Promoção do Conhecimento, Diálogo e Motivação - foi implementado e abarcou sugestões dos colegas e gestores. o publico alvo foram todos os colaboradores do setor com indicadores como Listas de Presença e preenchimento de Avaliação de Reação. Objetivos Melhorar o relacionamento entre os colaboradores, enfatizando a importância. do trabalho em equipe com desenvolvimento relacional e técnico em referencia ao atendimento ao cliente e outros processos de trabalho advindos. Conscientizar a importância do compartilhamento de informações e descrição dos serviços como metodologia para melhor gestão em benefício da Instituição; Desenvolver a importância do equilíbrio em ser um trabalhador na área da saúde; Valorizar o funcionário do setor [...] na área da saúde. Métodos Todas as etapas dos dois trabalhos foram pensadas e formatadas de acordo com as orientações oficiais para o Plano de Curso e baseados em jogos de cooperação psicopedagógicos que geram discussões. em setembro todos do setor foram ouvidos pela diretora, um a um e puderam comentar queixas e dar sugestões de melhorias que beneficiassem o setor. a diretora ouviu um a um e as sugestões foram anotadas, tabuladas e analisadas pelas chefias para que fossem propostas novas ações como feedback. em outubro por ocasião do dia do Funcionário Público aproveitou-se a ocasião para discorrer sobre a Responsabilidade, Autonomia, Flexibilidade e Valorização através de atividade que envolvia um discurso improvisado após sorteio das palavras. Todas as etapas foram demarcadas por diálogos informais. Resultados: a garantia de espaços de discussão junto a diretoria conquistados pelos funcionários e facilitado pelo gestor e a conscientização do trabalho em grupo com impacto qualitativo na mudança de postura. Feedback positivo quanto a sugestões estabelecendo coparticipação nas ações. Conclusões Ficou patente a importância da participação da diretoria no processo de escuta à queixa e sugestões de cada colaboradores e o espaço de reflexão sobre os impactos das decisões por ambos os lados, gestores e colaboradores com ênfase na aprendizagem.

Alves, Solange Evangelhista; Matos, Patricia Midoes de. Contornos Humanísticos em Gestão. In: Anais do Congresso Internacional de Humanidades \& Humanização em Saúde [= Blucher Medical Proceedings, num.2, vol.1]. São Paulo: Editora Blucher, 2014. ISSN 2357-7282

DOI 10.5151/medpro-cihhs-10430 